\title{
Wyrok Sądu Metropolitalnego w Katowicach (c. Sobański) z 29.12.2006 r. z tytułu bojaźni szacunkowej po stronie powódki
}

Ius Matrimoniale 13 (19), 221-225

2008

Artykuł został opracowany do udostępnienia w internecie przez Muzeum Historii Polski w ramach prac podejmowanych na rzecz zapewnienia otwartego, powszechnego i trwałego dostępu do polskiego dorobku naukowego i kulturalnego. Artykuł jest umieszczony w kolekcji cyfrowej bazhum.muzhp.pl, gromadzącej zawartość polskich czasopism humanistycznych i społecznych.

Tekst jest udostępniony do wykorzystania w ramach dozwolonego użytku. 


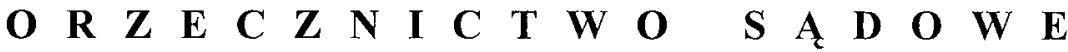 \\ Ius Matrimoniale 13 (19) 2008}

\section{Wyrok Sądu Metropolitalnego w Katowicach (c. Sobański) z 29. 12. $2006 \mathrm{z}$ tytułu bojaźni szacunkowej po stronie powódki}

\section{Przebieg sprawy}

ZW oraz RB zawarli małżeństwo 8. 9. 1984. Ważność tego małżeństwa zaskarżyła RB 27. 10. 1999. Sprawę prowadzono z tytułów symulacji oraz bojaźni szacunkowej - obydwa po obydwu stronach. Wyrokiem z 10.2. 2001 Sąd orzekł, że nie udowodniono nieważności małżeństwa $\mathrm{z}$ żadnego $\mathrm{z}$ rozpatrywanych tytułów. Wskutek apelacji powódki sprawa znalazła się w Trybunale II instancji. Trybunał ten wydał 20. 8. 2003 wyrok orzekający, że nie udowodniono nieważności małżeństwa $z$ tytułu symulacji ani też $z$ tytułu bojaźni szacunkowej po stronie pozwanego, udowodniono natomiast nieważność $\mathrm{z}$ tytułu bojaźni szacunkowej po stronie powódki. Z powodu zmiany adresu, o której powódka nie poinformowała Trybunału, nawiąano kontakt $z$ nią dopiero w styczniu 2006. Dnia 21. 3. 2006 wpłynęła do Sądu prośba powódki zaadresowana do Najwyższego Trybunału Sygnatury Apostolskiej o wyznaczenie któregoś z sądów kościelnych w Polsce do rozpatrzenia sprawy w Polsce. Najwyższy Trybunał Sygnatury Apostolskiej reskryptem z 6. 6. 2006 powierzył to zadanie Sąowi Metropolitalnemu w Katowicach. Akta sprawy nadeszły 3. 8. 2006. Tegoż dnia wyznaczono kolegialny skład Sądu do rozpatrzenia sprawy, której przedmiotem jest pytanie, czy udowodniono nieważność małżeństwa $\mathrm{z}$ tytułu bojaźni szacunkowej po stronie powódki. Powódka nie przedłożyła nowych wniosków dowodowych, pozwany nie zareagował na pisma Sądu. Akta sprawy uzupełniono o kopię protokołu kanonicznego badania narzeczonych.

\section{Prawny i faktyczny stan sprawy}

1. Normy prawa znajdujące zastosowanie w rozpatrywanej sprawie wyłożono poprawnie i wystarczająco w wyrokach poprzednich Instancji, nie zachodzi przeto potrzeba przypominania ich.

2. Trybunał II instancji uznał, że ,zebrany materiał dowodowy 
dostarcza przekonujących argumentów potrzebnych do uzyskania pewności moralnej odnośnie orzeczenia nieważności małżeństwa z tytułu bojaźni szacunkowej po stronie powódki". Znaczy to, że Trybunał II instancji osiagnął pewność, iż zależność powódki rodziła zniewolenie nie pozwalające powódce oprzeć się matce żądajacej zawarcia małżeństwa, przy czym przyczyną tego żądania była ciąża powódki.

3. Istotne $z$ punktu widzenia tytułu sprawy informacje zawarte $\mathrm{w}$ zeznaniach powódki zawieraja się w następujących wypowiedziach złożonych pod przysięga: , Moi rodzice wyszli z propozycja zawarcia malżeństwa, jak dowiedzieli się, że jestem $w$ ciqży. Ja nie chciatam, ale nie miatam nic do powiedzenia ... Nie kierowatam się mitościq ani chęciq zatożenia rodziny, lecz tylko ciaża $i$ wola rodziców. A także czutam się winna tego, co zrobitam. Rodzice mieli $\dot{z} a l$ do mnie, że ich zawiodlam... Gdyby nie ciaża, to w takiej sytuacji, jak wtedy byliśmy, na pewno z nim matżeństwa bym nie zawarla ... Ja wtedy myślatam tylko o studiach. Moi rodzice zadecydowali o tym matżeństwie. Mówili, że jeśli zrobię inaczej, to skazuję siebie i dziecko na taki stan, jaki będzie. A ponadto powiedzieli mi, że jeśli nie wyjde za pozwanego, to nie moge liczyć na żadna pomoc finansowa $z$ ich strony. Nie mialabym wtedy żadnych możliwości studiowania. Moi rodzice byli bardzo zdecydowani w swych wypowiedziach..., byli bardzo dobrzy, ale i konsekwentni ...".

Powódka stwierdza więc, że nie chciała małżeństwa, jednak z jej zeznań nie wynika jasno, czy jej decyzja na małżeństwo była wyłącznie następstwem stanowiska zajętego przez rodziców, czy też wynikła z dokonanej przez powódkę analizy całej sytuacji. Niektóre jej wypowiedzi sugeruja, że to nie bojaźń przed rodzicami, lecz rozsądek kazał jej zgodzić się na małżeństwo (np. „myślałam wtedy tylko o studiach”, „trwałam w tym przekonaniu, że nie chcę tego małżeństwa, a tylko mnie zmusza do tego sytuacja - ciąża i postawa rodziców i moje odczucia"). Dla oceny, jaka była wówczas faktyczna wola powódki, trzeba rozpatrzyć jej zeznania w świetle całego nagromadzonego materiału dowodowego.

4. Pozwany twierdzi, że to on wysunął propozycję małżeństwa, przyznaje też, że „decydująca była ciąża”. Zeznaje: „Nikt nas nie zmuszał do ślubu".

5. Zdecydowane są zeznania matki powódki: ,Pewnego dnia powiedziala mi, że jest w ciqży. Ja bytam w szoku, robiłam jej wymówki, 
przygadalam jej dużo, że powinna odpowiadać za to i nie widzę innego wyjścia, jak tylko zawarcie malzeństwa i to w jak najkrótszym czasie. Ona zaczęta plakać, że nie chce brać ślubu. Ja mówitam, że ślub musi wziać, że to jest konieczne dla dobra dziecka, że dziecko potrzebuje obojga rodziców. Obiecywałam, że jej pomożemy. Jeśli nie weźmie ślubu, to może liczyć tylko na siebie i nasze drzwi będa przed nia zamknięte. Watpię, czy ona databy sobie rade bez nas. Namawiatam jq do tego ślubu wiele razy, bo ona nie chciała się zgodzić. Wreszcie zgodzila się pod wptywem moich namów. Gdyby nie moje namowy, to uważam, że nie zdecydowataby się na ślub z pozwanym. Maż wiedziat o tej sprawie ode mnie $i$ on też powiedziat, że nie widzi innego wyjścia, jak tylko zawarcie matżenstwa. Maż powiedziat to tylko raz, ale dobitnie. A ona przed ojcem zawsze czuła respekt i jak coś powiedziat, to nie bylo dyskusji. Kilka dni po tych naszych rozmowach z córkq, pozwany przyszedt i powiedzial, że się z niq ożeni. Odczułam jednak, że pozwany decyduje się na to matżeństwo z obowiqzku. On byl w ogóle matomówny i nie okazywat swych uczuć. Wedhug mnie, decydujacym motywem zawarcia malżeństwa była ciaża i moje usilne, ostre namowy oraz postawa męża. Gdyby nie ciaża $i$ postawa moja i mego męża, to matżeństwa by nie byto. Córka nie robila tego chętnie i z radościq. Gdyby nie zawarta ślubu, bylaby pozbawiona naszej pomocy, nasze drzwi bytyby przed nia zamknięte i musialaby liczyć tylko na siebie".

Równie zdecydowane zdanie znajduje się w zeznaniach ojca powódki: „Zmusiłem do zawarcia zwiqzku matzeńskiego dla dobra dziecka, bo groziłem, że się jej rodzina wyrzeknie... Ja i żona zmuszalismy ja. $R$. byla nieraz uparta i trzeba byto wymuszać na niej postuszeństwo... Córka nie chciała, miata jakieś uprzedzenie, mówila, że jakoś wychowa dziecko ... Gdyby nie ciaża, to może by wcale do tego matzeństwa nie doszło... Miato miejsce groźne wywarcie nacisku przeze mnie na córke. Sprawa byta postawiona jednoznacznie $i$ ten strach przed konsekwencja zmusit ja do zawarcia zwiazku matżeńskiego".

Świadek IB. zeznaje, że powódka „w ogóle nie chciała wychodzić za mąż, nawet po tym, jak się dowiedziała, że jest w ciąży". Świadek uważa, że „w tym okresie powódka nie miałaby odwagi powiedzieć swym rodzicom „nie”. Świadkowi - jak zeznaje - „powódka mówiła przed ślubem, że to małżeństwo nie ma sensu, że w ogóle jest w bardzo trudnej sytuacji, bowiem rodzice nalegaja, a ona obawia 
się, że kiedy odmówi rodzicom, to straci ich miłość, kontakty osobiste. Obawiała się o swoją przyszłość".

6. Między zeznaniami stron zachodzą rozbieżności. Można by thumaczyć je tym, że pozwany nie wiedział, co dzieje się w domu powódki. Trudno jednak nie zauważyć dysproporcji między zeznaniami powódki i jej rodziców. W zeznaniach powódki brak wzmianki o jakimkolwiek jej sprzeciwie, twierdzi, że nie miała nic do powiedzenia. Brak sprzeciwu nie kłóci się z tezą o bojaźni szacunkowej (gdyż właśnie ów szacunek może wstrzymywać przed wyrażaniem sprzeciwu). Tymczasem jednak matka powódki zeznała, że powódka „nie chciała się zgodzić”, że „wreszcie” się zgodziła, że płacząc oznajmiała, iż nie chce ślubu. Jeszcze bardziej kategorycznie wyraża się ojciec powódki mówiąc o groźbach. Czyżby powódka zeznając zapomniała o tym wszystkim?

7. Wedle powódki i jej świadków przyczyną przymusu była ciąża i konsekwencje wynikające dla powódki $z$ urodzenia dziecka. Tymczasem powódka zeznała, że nastappiło „samoistne poronienie" i zaznacza ,jeszcze nie było trzeciego miesiąca". Nie jest jasne, czy chodzi o trzeci miesiąc ciąży czy o trzy miesiące po zawarciu małżeństwa. W pierwszym przypadku należałoby przypuszczać, że zawierając małżeństwo powódka nie była już w ciąży (wniosek taki nasuwałby się z zestawienia dat: strony były do protokołu przedślubnego 18. 7. 1984, małżeństwo zawarto 8. 9. 1984). Pozwany zeznając mówił o „niewyjaśnionej kwestii poronienia”. Sąd usiłował wyjaśnić tę sprawę, ale powódka nie odpowiedziała na zapytanie Sądu.

8. Lektura akt sprawy nasuwa jeszcze inne watpliwości, niedotyczące bezpośrednio przedmiotu sporu, jednak wymagające uwzględnienia przy analizie materiału dowodowego. I tak: Powódka zeznała, że rozwód orzeczono w 1993 r. na wniosek pozwanego. W skardze pisze powódka, że pozwany zażądał rozwodu w 1992 r. i „W niedługim czasie po uzyskaniu rozwodu zawarł nowy związek cywilny". Tymczasem w aktach sprawy I instancji znajduje się kserokopia wyroku Sąu Rejonowego w (...) z 7. 5.1992 orzekającego rozwód małżeństwa stron „z powództwa RW.”. Pozwany z kolei twierdzi zarówno w piśmie z 5. 12. 1999, jak też zeznając 24. 3. 2000 - że najpierw, w 1992 r. orzeczono rozwód z powództwa powódki, po czym strony ponownie zawarly zwiazek cywilny, rozwiązany w 1993 r. z powództwa pozwanego. Twierdzenie pozwanego o dacie rozwodu $\mathrm{z}$ powództwa powódki znajduje oparcie w kopii wyroku rozwodo- 
wego. Brak w aktach udokumentowanego śladu dwukrotnego rozwodu, jedynie ojciec powódki zeznał „dwukrotnie rozstawali sie". Sąd usiłował wyjaśnić zachodzące rozbieżności, niestety powódka - mimo przynaglenia - nie odpowiedziała na pisma Sądu. Jeśliby przyjać za prawdziwe twierdzenie o dwukrotnym zawieraniu związku cywilnego, nasuwałby się wniosek, że nawet jeśli wola małżeństwa powódki była dotknięta brakiem z powodu bojaźni szacunkowej, to decyzja na ponowne (cywilne) związanie się stwarza domniemanie o naprawieniu zniewolenia małżeńskiego (k. 1158 § 2).

9. Wyłożone wyżej wątpliwości, wyrastające $\mathrm{z}$ konfrontacji zeznań oraz niewyjaśnionych faktów, nie pozwalają Sądowi osiagnąć moralnej pewności co do zawarcia przez powódkę małżeństwa pod wpływem bojaźni szacunkowej.

Wobec powyższego Sąd odpowiada przecząco na pytanie procesowe i orzeka, że nie udowodniono nieważności małżeństwa. Tym samym Sąd uchyla wyrok Trybunału II instancji w części orzekającej nieważność małżeństwa. 